\title{
Evaluation of the impact of the leached and solubilized extracts on the germination of cabbage seeds (Brassica oleracea var. capitata)
}

\author{
Sérgio Thode Filho', Leonardo Corrêa de Souza² ${ }^{2}$ Emanuele Nunes de Lima Figueiredo \\ Jorge $^{3}$, Marcelo Fonseca Monteiro de Sena ${ }^{4}$, Heider Alves Franco ${ }^{5}$ \\ 1,3,4Professor at the Federal Institute of Education, Science and Technology of Rio de Janeiro - IFRJ, Campus Duque de \\ Caxias, RJ, Multidisciplinary Laboratory Waste Management - LMGR. sergio.thode@ifrj.edu.br \\ ${ }^{3}$ Graduation Student at the University UNIGRANRIO, Rio de Janeiro, RJ, Multidisciplinary Laboratory Waste \\ Management - LMGR
}

${ }^{5}$ Professor at the Federal Institute of Education, Science and Technology of Rio de Janeiro - IFRJ, Campus Duque de Caxias, RJ, Multidisciplinary Laboratory of the Biology - LMB.

${ }^{6}$ Professor at the Federal Institute of Education, Science and Technology of Rio de Janeiro - IFRJ, Campus Pinheiral, RJ, Multidisciplinary Laboratory of Agro-Environmental Technology - LAMTAA

\begin{abstract}
The germination and seedling root development trials have been used to evaluate and quantify the toxicity of watersoluble compounds as well as mixtures of complex substances, leached, among others. The objective was to evaluate the impact of leached and solubilized extracts of coffee waste on the germination and development of cabbage seedlings ( $B$. oleracea var. Capitata), as well as to evaluate the physical and chemical properties of these extracts. The extracts were prepared according to the Brazilian Association of Technical Standards 10.005 and 10.006, respectively. The experimental design had 7 treatments for the test group (leached), 7 treatments for the test group (solubilized) and one control group. The control group was composed of $4 \mathrm{~mL}$ distilled water. It was verified that from the lowest dosage administered (0.1 $\mathrm{mL}$ ) there was an inhibition in the germination of $30 \%$ for both extracts. Starting the dose with $0.7 \mathrm{~mL}$ of leached, no root growth was observed. The determination of LOEC was established in the treatments with $0.1 \mathrm{~mL}$ for both extracts.
\end{abstract}

Keywords: Leached, Solubilized, Coffee Waste, Germination.

\section{Introduction}

The continuous changes in lifestyle, ind ustrial and commercial growth in many countries of the world in recent decades have been accompanied by rapid increases in the production of urban and industrial waste. This evolution represented an increase in income and quality of life, however, culminating with a growing increase of toxic elements and components, which directly interfere with the quality and potential of natural resources (RENOU et al., 2008). 
The residual biomasses of coffee and other beverages generated in coffee shops, restaurants, residences, bars among others do not have registers due to the difficulty of quantifying this type of waste in different places (FREITAS, 2000; VEGRO e CARVALHO, 2006; RAMALAKSHMI et al., 2009; PANUSA et al., 2013).

The chemical and physical characterization of these elements points out its contaminating potential, however, it is fundamental to evaluate its biological implications and possible interactions. While the chemical analyzes identify and quantify the concentrations of toxic substances, toxicity tests assess the effect of these substances on biological systems (COSTA et al., 2008; KALCIKOVA et al., 2011).

The main objectives the ecotocicological are to identify the risks associated with a substance and to determine under what conditions of exposure these risks are induced. Toxicology as a science serves both to protect living beings and the environment from harmful effects caused by toxic substances and to facilitate the evaluation of more selective harmful chemical agents such as clinical drugs and pesticides. About eleven million chemicals are known and only a small percentage is well studied in relation to their effects and dynamics in the environment (ZAKRZEWSKI, 1994; MANNING and TIENDMANN, 1995; HODGSON, 2004).

To analyze the toxic effects for substance or mixed substances improperly discarded should be performed toxicity tests that aim to predict the potential impact of a xenobiotic (toxic agent) on environment (FLOHR et al., 2005). For such tests, certain organisms are used and they are called test organisms.

In this context, germination and seedling root development trials have been used to evaluate and quantify the toxicity of water-soluble compounds as well as mixtures of complex substances, leachate, sediments among others (BOWERS, et al., 1997). These substances are submitted to acute phytotoxicity tests, aiming at evaluating both lethal effects through inhibition of seed germination and sublethal effects via root development (USEPA, 1996; OECD, 2003). The objective of this work was to evaluate the impact of leached and solubilized extracts of coffee waste on the germination and development of cabbage seedlings (B. oleracea var. capitata), as well as to evaluate the physical and chemical properties of these extracts.

\section{Materials and methods}

\subsection{Preparation of extracts}

The leached and solubilized extracts were prepared according to the Brazilian Association of Technical Standards 10.005 and 10.006, respectively (Brazilian Association of Technical Standards, 2004a, 2004b). To prepare the leached extract, $50.0 \mathrm{~g}$ samples of traditional Pilão ${ }^{\circledR}$ coffee waste (about 70\% Arabica and 30\% Robusta, grain size $<9.5 \mathrm{~mm}$ ) were transferred to polyethylene bottles and treated with $1.0 \mathrm{~L}$ of the extraction solution $(5.7 \mathrm{~mL}$ of glacial acetic acid, $64.3 \mathrm{~mL}$ of $1.0 \mathrm{~mol} / \mathrm{L} \mathrm{NaOH}$ and $930 \mathrm{~mL}$ of Milli-Q water). The bottles were closed and shaken for about $18 \mathrm{~h}$ using a rotary shaker at $100 \mathrm{rpm}$ (Nova Etica ${ }^{\circledR}$ model 430) at room temperature, and then filtered through a $0.45 \mu \mathrm{m}$ membrane.

To prepare the solubilized extract, $250 \mathrm{~g}$ samples of Pilão ${ }^{\circledast}$ coffee waste were transferred to polyethylene bottles and treated with $1 \mathrm{~L}$ of ultra-pure water. The bottles were closed, shaken for 5 min using a rotary shaker at room temperature and then left standing for 7 days before filtering through a $0.45 \mu \mathrm{m}$ membrane.

\subsubsection{Physicochemical analysis}

The physicochemical parameters such as $\mathrm{pH}$, conductivity, TDS (total dissolved solids) and salinity were determined in the leached and solubilized extracts using a multi-parameter analyzer (COMBO 5 - AKSO). 


\subsection{Seed sampling}

To perform the tests were used cabbage seeds (B. oleracea var. capitata). The seeds were from ISLA PAK ${ }^{\circledR}$ with $99.7 \%$ purity, $85 \%$ germination and validity until July / 18, directly, without any previous procedure.

\subsubsection{Phitotoxicity test}

Toxicity tests about radicle germination and development using cabbage seeds (B. oleracea var. capitata) were performed to evaluate both, the lethal inhibition effects on seed germination and the sub lethal effects on radicle development (SOBRERO and RONCO, 2004 and OECD, 2003).

The experimental design had 7 treatments for the test group (leached), 7 treatments for the test group (solubilized) and one control group. The control group was composed of $4 \mathrm{~mL}$ deionized water. The treatments for the test group were: (a) 0,1 mL extract leached $+3,99 \mathrm{~mL}$ of deionized water, (b) 0,4 mL extract leached $+3,6 \mathrm{~mL}$ deionized water, (c) 0,7 mL mL extract leached $+3,3 \mathrm{~mL}$ deionized water, (d) $1 \mathrm{~mL}$ extract leached $+3 \mathrm{~mL}$ deionized water, (e) $2 \mathrm{~mL}$ extract leached $+2 \mathrm{~mL}$ deionized water, (f) $3 \mathrm{~mL}$ extract leached $+1 \mathrm{~mL}$ deionized water and $(\mathrm{g})$ $10 \mathrm{~mL}$ only extract leached (without added water). The same procedure was used for the solubilized extract (extract + water). For all treatments, had three replicates.

Additionally, twenty seeds of cabbage were placed in a Petri dish of $9.5 \mathrm{~cm}$ in diameter and moistened with the solution prepared according to established treatments, having as substrate a qualitative filter paper (porosity $14 \mu \mathrm{m}$ ). The Petri dishes were conditioned in a BOD incubator incubator with photoperiod (CIENLAB and model CE-300/350-F) at a temperature of $25 \pm 2^{\circ} \mathrm{C}$ for 12 h light / 12 h dark.

\subsubsection{Phytomass assessement}

At the end of $120 \mathrm{~h}$ (5 days), the following parameters were evaluated: number of germinated seeds and length of rootlets.

In order to determine the sublethal effects, it was sought to identify the concentration of unobserved effect (NOEC), which corresponds to the highest concentration / dose of toxic agent that does not cause deleterious effect statistically significant in the organisms in the time and in the conditions of the test; and the observed effect concentration (LOEC), which corresponds to the lowest concentration / dose of toxic agent that causes statistically significant deleterious effects on organisms at the time of exposure and the test conditions (RONCO, BAEZ and GRANADOS, 2004). The determination of NOEC and LOEC were carried out from the comparison between the means of the root length.

\subsection{Statistical analysis}

The germination tests measurements and the length of rootlets were analyzed using a graduated ruler and a digital caliper. After these measurements, the parameters averages were calculated and Tukey's test used to evaluate the significance at 0.05 (5\% probability) among them (COSTA NETO, 1977; MILLER; MILLER, 1993).

All calculations and graphs presented in this work were performed by BioEstat 5.0 and SigmaPlot 12.5 software. 


\section{Results and Discussion}

The table 1 shows the physicochemical properties of the leached and solubilized extracts. It can be seen that leached extract showed higher conductivity, total dissolved solids (TDS) and salinity than the solubilized extract. In addition, was observed a very acid $\mathrm{pH}$. The extract solubilized although prepared in aqueous medium also presented acidic characteristics.

In addition, according to Technical Standard NBR 10.004 Solid waste - Classification (ABNT, 2004c), this waste is classified as: Class II A, Not Hazardous - Not Inert.

Table 1. Physicochemical properties of the leached and solubilized extracts.

\begin{tabular}{ccccc}
\hline Coffee Waste & $\mathbf{p H}$ & $\begin{array}{c}\text { Conductivity } \\
(\boldsymbol{\mu S} / \mathbf{c m})\end{array}$ & $\begin{array}{c}\text { TDS } \\
(\mathbf{p p m})\end{array}$ & $\begin{array}{c}\text { Salinity } \\
(\mathbf{p p m})\end{array}$ \\
\hline $\begin{array}{c}\text { Leached } \\
\text { Solubilized }\end{array}$ & 4.9 & 530 & 345 & 272 \\
\hline
\end{tabular}

The average values of the germination percentage as a function of the different treatments with the leached and solubilized extracts are shown in Figure 1. The control group presented $76 \%$ germination. It was verified that from the lowest dosage administered $(0.1 \mathrm{~mL})$ there was an inhibition in the germination of $30 \%$ for both extracts. For the leached, the percentage of inhibition for treatment with $0.4 \mathrm{~mL}$ was $66 \%$ and from $0.7 \mathrm{~mL}$ the germination rate was zero. The treatments with 0.4 and $0.7 \mathrm{~mL}$ of solubilized presented results lower than $50 \%$ (46\%). To $1 \mathrm{~mL}$ of the solubilized the inhibition on germination was $45 \%$. The same inhibitory behavior was observed for the other treatments ( $2 \mathrm{~mL}, 61 \%, 3 \mathrm{~mL}, 74 \%, 10 \mathrm{~mL}, 87 \%)$. The p-value found for the treatments was 0.0003 . Significant differences were observed between the control group and the Tukey test $(\mathrm{p}<0.05)$. The quadratic regression describes a decreasing behavior for the germination response in relation to the different treatments with the leached and solubilized extracts.

According to Beweley and Black (1994) and Shafaei et al. (2014) the germination process depends on the presence of water to the seed matrix, the oxygen content and some external environmental factors such as light and temperature. Therefore, these results indicate that the different dosages of leached and solubilized extracts had an influence on the percentage of germination of cabbage seeds (B. oleracea var. capitata).

Santos et al. (1992) shows that, in addition to water, the salinity of the local significantly influences the germinative response of the species because it causes a reduction of the water potential of the local. In this sense, it hinders the kinetics of water absorption, but also facilitates the entry of toxic ions into imbibed seeds. As the leached is a saline extract, the deleterious effects found in this study may be due to the increased concentration of the salts which should impair the germination and initial development of the seedling. 


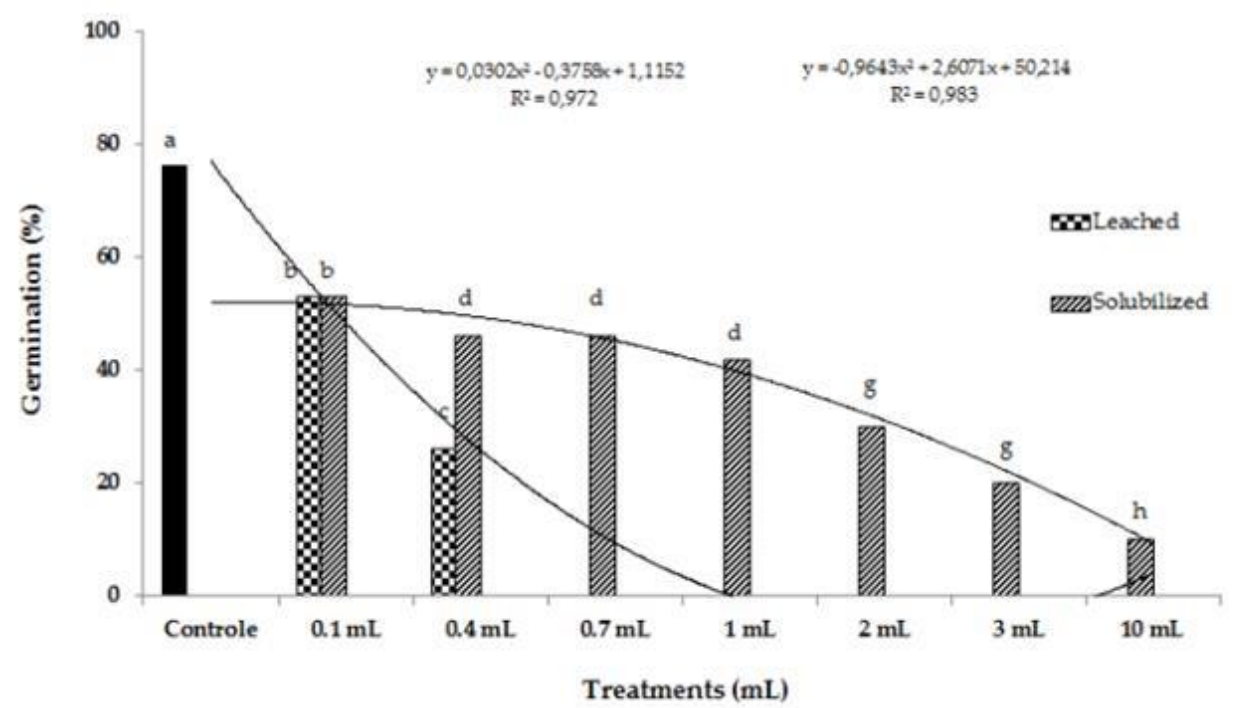

Figure 1. Evaluation of the percentage of germination of cabbage seeds (B. oleracea var. Capitata) contaminated with different dosages of the leached extract and solubilized from the coffee grounds. Means followed by the same lowercase letter do not differ statistically from each other by Tukey test $(\mathrm{p}<0.05)$.

The medium values of root structure growth in function of the different treatments with the leached and solubilized extracts are shown in graph 2 . The control group showed a growth of $47 \mathrm{~mm}$. From the lower dosage $(0.1 \mathrm{~mL})$ there was an inhibition in the radicle growth of $47 \%$ for the leached and $17 \%$ for the solubilized extracts. For the dose with $0.4 \mathrm{~mL}$ of leached the percent inhibition was $66 \%$. From $0.7 \mathrm{ml}$ of leachade the growth of the radicle was zero. Treatments with 0.4 and $0.7 \mathrm{~mL}$ of the solubilized presented growth inhibition lower than $45 \%$ ( $38 \%$ and $42 \%$, respectively). From $1 \mathrm{~mL}$ of the solubilized extract, an inhibition greater than $50 \%$ was found. Treatment with $10 \mathrm{~mL}$ showed a $79 \%$ inhibition of root growth. The p-value found for the treatments was 0.0010. Significant differences were observed between the control group and the Tukey test $(\mathrm{p}<0.05)$. The quadratic regression describes a decreasing behavior for the lenght of rootles growth response as a function of the different treatments with the leached and solubilized extracts. It was not possible to identify NOEC because the lowest dose was able to promote subtly perceptible effects by inhibiting the development of the radicle. The determination of LOEC was established in the treatments with $0.1 \mathrm{~mL}$ for both extracts.

It was verified that the acidic character of the extract and that the salinity present in the leached of the coffee grounds influenced significantly the germination process of the cabbage. Bernardes et al. (2015) evaluating the germination of cabbage seeds have identified that the salt as for example the $\mathrm{KCl}$ can provoke more aggressive results on the germination and the development of the seedlings than the $\mathrm{NaCl}$. This statement corroborates with the results found in the present study from the variables evaluated.

The evaluation of the effect on the elongation of the radicle of the seedlings may reflect the toxicity of the soluble compounds present at such low concentration levels that they are not sufficient to inhibit germination but may delay or inhibit the root elongation process depending on the mode and site of action of the compounds. Thus, inhibition of root elongation shows a sensitive sublethal indicator for evaluating biological effects on plants (TAMADA et al., 2012). 


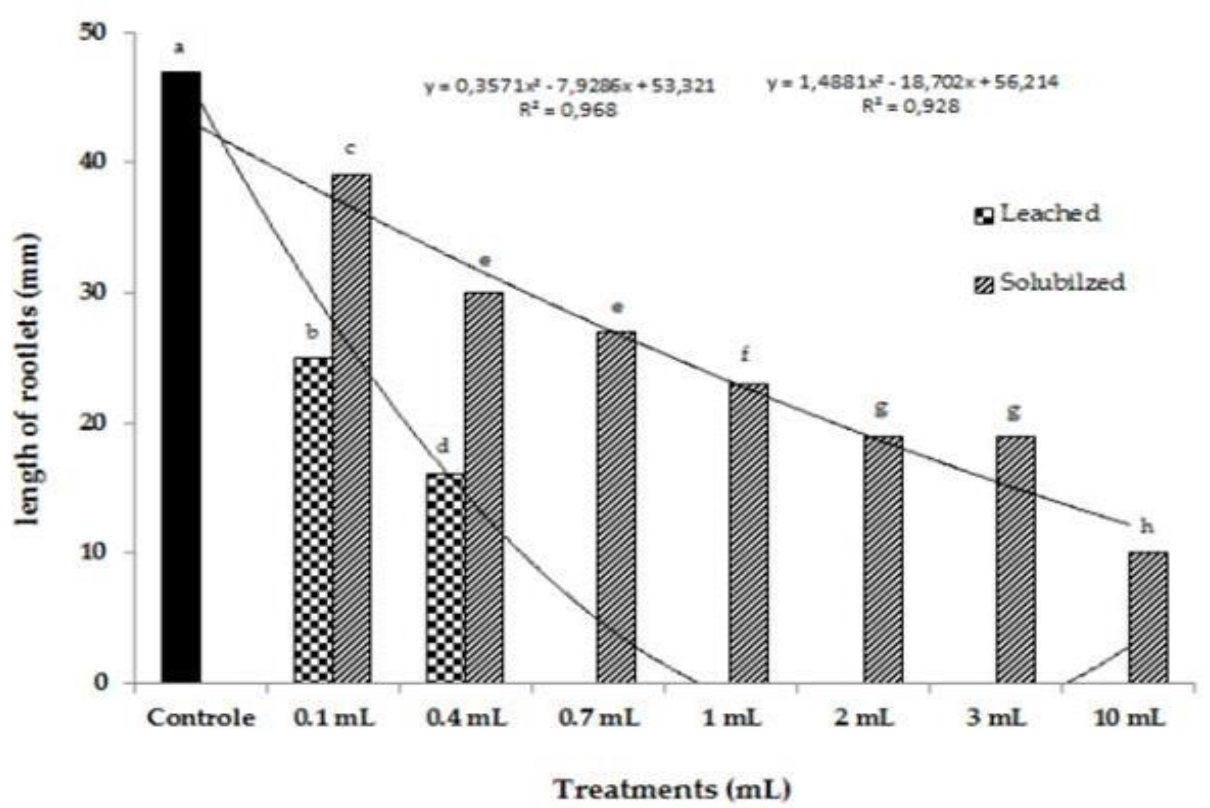

Figure 2. Radicle lenght of rootles on the germination of cabbage seeds (B. oleracea var. capitata) contaminated with different dosages of the leached extract and solubilized from the coffee grounds. Means followed by the same lowercase letter do not differ statistically from each other by Tukey test $(\mathrm{p}<0.05)$.

Guedes et al. (2011) verified that the root length was affected as the salinity levels increased in Chorisia glaziovi seeds. Thus, the higher the dose of the pollutant (leached and solubilized) introduced, the lower the root growth, mainly due to the high salinity of the effluent.

The accumulation of salts in the root zone at high concentrations are sufficient to restrict water absorption by the plant. This can lead to a water deficiency state, and cause symptoms very similar to those caused by lack of water (AYERS \& WESTCOT, 1999).

None of the extracts studied presented morphological benefits to the seedlings (Figure 1 and 2). The leached extract had a more acidic and saline character than the solubilized one. The length of the radicle underwent a strict reduction, with visible growth inhibition occurring with increasing the dose of the leached (Figure 3).

The ability of plants to obtain water and mineral nutrients from soil was related to their ability to develop an extensive root system (TAIZ et al., 2017). It is assumed, therefore, that it can severely compromise the vegetative development of this plant, since, with the root system compromised, the plant is not able to absorb the essential elements to complete its cycle.
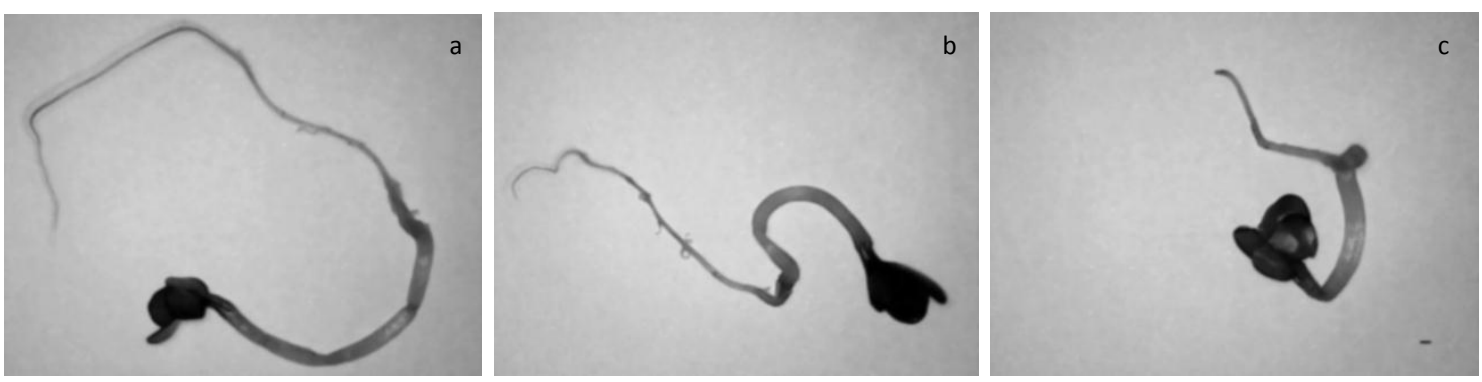

Figure 3. Radicle lenght of rootles on the germination of cabbage (B. oleracea var. capitata) seeds contaminated with different dosages of the leach extract from the coffee grounds. (a) control; (b) $0.1 \mathrm{ml}$ of leached; (c) $0.4 \mathrm{ml}$ of leached. All the figures were evaluated with the same scale $(1 \mathrm{~mm})$. 
The same inhibitory behavior was observed for the solubilized extract, but with less severe effect; Being this gradual (Figure 4). It is evidenced that with the increase of the solubilized dose, the morphological anomaly in the root system is also accentuated. Thus, it can be seen that these seedlings could not survive in field conditions, since the ability to absorb water and nutrients is greatly impaired.

Thus, the presence of a less developed root system in a plant leads a lower production of cytokines, due to the lower number of root ends, consequently the growth rate was reduced and survival was also compromised in adverse environments, specially of marked water deficiency (REIS et al., 2006).
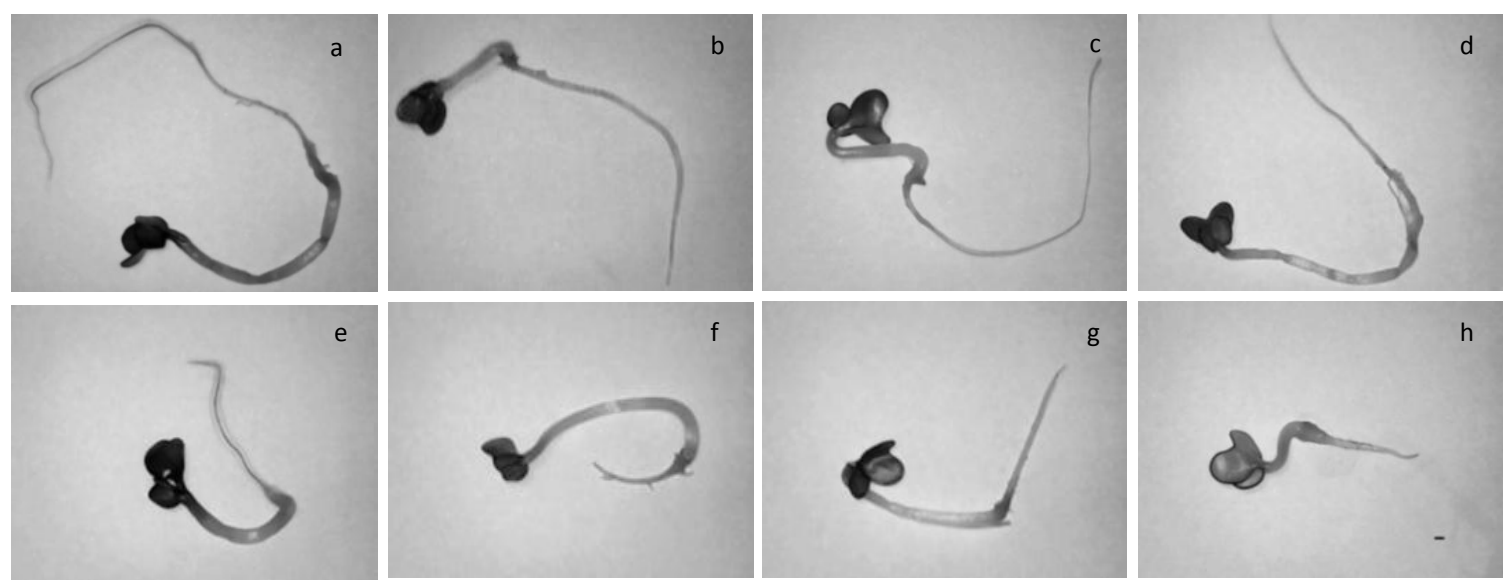

Figure 4. Radicle lenght of rootles on the germination of cabbage (B. oleracea var. capitata) seeds contaminated with different dosages of the solubilized extract from the coffee waste. (a) control; (b) 0,1 mL de solubilized; (c) 0,4 mL de solubilized; (d) 0,7 mL de solubilized; (e) 1,0 mL solubilized; (f) 2,0 mL de solubilized; (g) 3,0 mL de solubilized e (h) 10,0 $\mathrm{mL}$ de solubilized. All the figures was evaluated with the same scale $(1 \mathrm{~mm})$.

\section{Conclusion}

The leached and solubilized coffee waste are classified as a not hazardous, not inert residue due to their solubilizing ability. Therefore, its final destination should employ some special measures of collection and protection of the environment. There was a negative effect on the germination rate and root growth for both extracts under study, due to the increase of the doses tested. It was verified that from the lowest dosage administered $(0.1 \mathrm{~mL})$ there was an inhibition in the germination of $30 \%$ for both extracts. Starting the dose with $0.7 \mathrm{~mL}$ of leached, no root growth was observed. The determination of LOEC was established in the treatments with $0.1 \mathrm{~mL}$ for both extracts.

\section{References}

ASSOCIAÇÃO BRASILEIRA DE NORMAS TÉCNICAS. NBR 10.005: Procedimento para obtenção de extrato lixiviado de Resíduos Sólidos. Rio de Janeiro: 2004a.

ASSOCIAÇÃO BRASILEIRA DE NORMAS TÉCNICAS. NBR 10.006: Procedimento para obtenção de extrato solubilizado de resíduos sólidos. Rio de Janeiro: 2004b.

ASSOCIAÇÃO BRASILEIRA DE NORMAS TÉCNICAS. NBR 10.004: Resíduos sólidos Classificação. Rio de Janeiro: 2004c. 
AYERS, R. S.; WESTCOT, D. W. A qualidade da água na agricultura. Campina Grande, UFPB, 1999. 153p.

BEWLEY, J. D.; BLACK, M. Seeds: Physiology of Development and Germination. (second ed.) Plenum Press, New York, 1994.

BERNARDES, P. M.; MENGARDA, L. H. G.; LOPES, J. C. NOGUEIRA, M. U.; RODRIGUES, L. L. Qualidade Fisiológica de Sementes de Repolho de Alta e Baixa Viabilidade sob Estresse Salino. Nucleus, v.12, n.1, abr. 2015.

BOWERS, N., PRATT, J.R., BEESON, D., LEWIS, M., 1997. Comparative evaluation of toxicity using lettuce seeds Soil Soil and ciliates. Environ. Toxicol. Chem., Vol. 16, no. 2, p. 207-213.

COSTA, C. R.; OLIVI, P.; BOTTA, C. M.; ESPINDOLA. E. L. G. A toxicidade em ambientes aquáticos: discussão e métodos de avaliação. Quimica Nova. v. 31 n. 7, p. 1820-1830, 2008.

COSTA NETO, P. L. O. Estatística. São Paulo: Edgard Blücher, 1977. 264p.

FLOHR, L. et al. Classificação de resíduos sólidos industriais com base em testes ecotoxicológicos utilizando Daphnia magna: uma alternativa. Biotemas, Florianópolis, v. 18, n. 2, p. 7-18, 2005.

FREITAS, S.P.; MONTEIRO, P.L.; LAGO, R.C.A. Extração do óleo da borra do café solúvel com etanol comercial. I Simpósio de Pesquisa dos cafés do Brasil, Industrialização. Poços de Caldas. p.740-743, 2000.

GUEDES RS; ALVES EU; GALINDO EA; BARROZO LM. Estresse salino e temperaturas na germinação e vigor de sementes de Chorisia glaziovii O.Kuntze. Revista Brasileira de Sementes 33: 279-288. 2011.

HODGSON, E. Modern Toxicology. North Carolina State: John Wiley \& Sons, Inc., Publication, 2004.

KALCIKOVA, G.; VAVROVA, M.; ZAGORC-KONCAN, Z., GOTVAJN, A.Z. Seasonal variations in municipal landfill leachate quality. MEQ: An International Journal, v. 22, p. 612-619, 2011.

MANNING, W.J.; TIEDMAN, A.V. Climate change: potential effects of increased atmospheric carbon dioxide (CO2), ozone (O3) and ultraviolet-B (UV-B) radiation on plant desseases - review paper. Environmental Pollution, v. 88, p. 219-145. 1995.

MILLER, J.C.; MILLER, J.N. Statistics for analytical chemistry. 3. ed. Chichester: Ellis Horwood, 1993. 233p.

ORGANIZATION FOR ECONOMIC COOPERATION AND DEVELOPMENT - OECD Terrestrial Plant Test: 208: Seedling Emergence and Seedling Growth Test. Guideline for the Testing of Chemicals Proposal for Updating Guideline 208, 2003.

PANUSA, A.; PETRUCCI, R.; MARROSU, G.; LAVECCHIA, R.; ZUORRO, A.; (2013) Recovery of Natural Antioxidants from Spent Coffee Grounds. Journal of Agricultural and Food Chemistry . v. 61, p.4162 -4168. 
RAMALAKSHMI, K.; RAO, L.J.M.; TAKANO -ISHIKAWA, Y.; GOTO, M. (2009). Bioactivities of low -grade green coffee and spent coffee in different in vitro model systems. Food Chemistry. India. v.115, p.79 -85.

REIS, G. G. dos; REIS, M. das G. F.; FONTAN, I. da C. I.; MONTE, M. A.; GOMES, A. N.; OLIVEIRA, C. H. R. de; Crescimento de raízes e da parte aérea de clones de híbridos de Eucalyptus grandis X Eucalyptus urophylla e de Eucalyptus camaldulensis X Eucalyptus spp submetidos a dois regimes de irrigação no campo. R. Árvore, Viçosa-MG, v.30, n.6, p.921-931, 2006.

RENOU, S.; GIVAUDAN, I.G.; POULAIN, S.; DIRASSOUYAN, F.; MOULIN, P. Landfill leachate treatment: Review and opportunity. Journal of Hazardous Materials, 150 (2008) 468-493.

RONCO, A.; BÁEZ, M. C. D.; GRANADOS, Y. P. Em Ensayos Toxicológicos y Métodos de Evaluación de Calidad de Aguas - Estandarización, Intercalibración, Resultados y Aplicaciones; Morales, G. C., ed.; Centro Internacional de Investigaciones para el Desarrollo: Ottawa, 2004, cap. 1.

SANTOS, V.L.M.; CALIL, A.C.; RUIZ, H.A.; ALVARENGA, E.M.; SANTOS, C.M. Efeito do estresse salino e hídrico na germinação e vigor de sementes de soja. Revista Brasileira de Sementes, Pelotas, v. 14, n.2, p.189-194, 1992.

SHAFAEI, S. M.; MASOUMI, A. A.; ROSHAN, H. Analysis of water absorption of bean and chickpea during soaking using Peleg model. Journal of the Saudi Society of Agricultural Science, 2014.

SOBRERO, M. C.; RONCO, A. Ensayo de toxicidad aguda con semillas de lechuga (Lactuca sativa L.). In: Ensayos toxicológicos y métodos de evaluación de calidad de aguas. Ottawa, Canadá, IDRC/IMTA. Ed., v. 4, p. 71-79, 2004.

TAIZ, L. et al. Fisiologia e desenvolvimento vegetal. 6. ed. Porto Alegre: Artmed, 2017.

TAMADA, I. S.; MONTAGNOLLI, R. N.; LOPES, P. R. M.; BIDOIA, E. D. Toxicological evaluation of vegetable oils and biodiesel in soil during the biodegradation process. Brazilian Journal of Microbiology. p. 1576-1581, 2012.

USEPA, 1996 - United States Environmental Protection Agency - Seed Germination / Root Elongation Toxicity Tests. Ecological Effects, Tests Guidelines.

VEGRO, C. L. R.; CARVALHO, F. C. (2006). Disponibilidade e utilização de resíduos gerados no processamento agroindustrial do café. Inf. Econ., v. 24, p. 9 -16.

ZAKRZEWSKI, S. F. Principles of Environmental Toxicology. Washington: American Chemical Society, 1994. 